\title{
The natural transformations of the Northern Kulunda in the second half of the Holocene based on studying the microbiomorphic profile of swampy phytocenosis
}

\author{
V. L. Paradossky ${ }^{1}$, Yu. V. Pechatnova, ${ }^{1}$ M. Y. Solomonova ${ }^{1}$ \\ ${ }^{1}$ Altai State University \\ Lenina St. 61, Barnaul, 656049, Russian Federation. \\ E mail: amatsyura@gmail.com
}

\section{Received: 15.08.2019 Accepted: 26.09.2019}

\begin{abstract}
The article presents the analysis of the microbiomorphic soil profile of the swampy meadow. Phytoliths, spicules of sponges and Rhizopoda shells are abundant in the soil. There are spores of fungus and mosses, as well as zoogenic material. The change in the natural conditions of the object during the second half of the holocene was reconstructed based on the obtained data. Differences in the content of microbiomorphs in different horizons of the soil profile of the swampy meadow correspond to the general regional and local processes of climate and vegetation dynamics in Northern Kulunda and adjacent territories.
\end{abstract}

Key words: Holocene; Microbiomorphic profile; Phytoliths; Pollen; Rhizopoda; Spores; Sponges

\section{Introduction}

Knowing, how the environment has evolved in the past, is important for assessing possible future changes. Investigations of the climate fluctuations and vegetation changes in the holocene (Rudaya et al., 2016; Rudaya et al., 2018; Zhilich et al., 2017) due to the human appearance and expansion the role of human influence on nature (Kiryushin 2017, 2019; Papin et al., 2018; Sitnikov et al., 2014; Fedoruk et al., 2017) are significant for the territory of Northern Kulunda. Landscapes of the Kulundinskaya steppe were formed in the holocene in the unstable climate (Hotinskiy et al., 1979; Orlova, 1990; Zyikin et al., 2011; Silanteva, 2008; Blyakharchuk, 2009) and under the influence of pastoral crops (Kiryushin, 2017, 2019; Papin et al., 2018). The materials of archaeological sites often study human influence on the vegetation formation. So, the processes of forest clearing and steppe formation of local territories, which are reconstructed on the basis of phytoliths analysis (Solomonova et al., 2016, 2017), are noted for the some pastoral crops on the territory of Northern Kulunda in the second half of the holocene.

These processes were matched up the general trend of increasing aridity of the region, proven by palynological investigations of adjacent territories (Rudaya et al., 2012; Zhilich et al., 2016).

The expansion of ideas about the interaction between human and nature is possible due to attracting new research methods. Both palynological or phytolytic methods, and also the general analysis the totality of microbiomorphic or non-pollen palynomorphs have the wide paleoecological potential (McCarthya et al., 2018; Misumi et al., 2018; Demske et al., 2013; Khokhlova et al., 2019; Rusakov et al., 2018). Initial data indicates that such analysis is perspective (Paradossky, Solomonova, 2018). The research group is the microbiomorphic profile of the swampy meadow.

\section{Materials and Methods}

The object of investigation is the swampy meadow located in the ancient floodplain of the river Burla (Khabarovsky district, Altai Territory, Russia). The total projective coverage is $100 \%$. Dominated by: Saussurea amara L. D.C. (cop 2) and Scolochloa festucacea (Willd.) Link (cop 3). In the grassy abundance of hygrophytes: Alopecurus arundinaceus (sp), Bolboschoenus planiculmis (F. Schmidt) T.V. Egorova (sp), Phragmites australis (sp). Among grasses Agrostis gigantea (sp) is also found. Abundant forbs: Inula britannica L. (sp), Lactuca tatarica (L.) C.A. May. (sol), Lycopus exaltatus L. (sp), Stachys palustris L. (sp), Plantago cornuti Gouan (sp), Potentilla anserina (sp) and Ptarmica cartilaginea (Ledeb. ex Rchb.) Ledeb. (sp).

Soils on the site are peat-bog, peat depth up to $50 \mathrm{~cm}$, below is the whitish layer of sapropel. That is, earlier there was the lake, then there was the period of water flow. When the plot had overgrown with herbs, the processes of swamping began, which formed the thickness of the peat. At the end of the Atlantic period, the archaeological eneolithic settlement Novoilinka-VI was located by the lake. There is an evidence of lake pollution by human. It is highly probable that the change of hydrological regime has become the main reason for people leaving the settled territories (Goleva, Kiryushin, 2015).

The method of enrichment the samples with microbiomorphs consists in the fact that before the investigation the sample must be sieved through the sieve with a $0.25 \mathrm{~mm}$ cell and transferred to the $1000 \mathrm{ml}$ heat-resistant measuring battery cup. After this, the sample is treated with the $5 \%$ hot solution of sodium pyrophosphate (up to the level of $200 \mathrm{ml}$ ), and after 2 hours it is added with hot water to the level of $1000 \mathrm{ml}$, after these the sample settles for a day. After the time, the sample is washed every 3 hours until the supernatant liquid becomes clear. The next step is drying the sample in the water bath, followed by centrifugation the sample with the heavy liquid (KI and CdI solution, specific gravity is 2.2). Centrifugation is carried out for 20 minutes at 2 thousand rpm; then the layer of heavy liquid with the upper part of the precipitate are mixed and centrifuged again. The upper layer of liquid, enriched with pollen, is poured into the glass with a volume of $250 \mathrm{ml}$ and diluted 4 times with distilled water. 
Collection and centrifugation in narrow-conical tubes at 2 thousand rpm for 15 minutes 3 times are carried out after sedimentation of the sample for a day (each time draining the supernatant and topping up the tube with distilled water to wash off heavy liquid). The final step of enriching the sample is drying in the water bath.

The Olympus BX-51 microscope using the Olympus XC-50 digital camera and cellSens Standard software with the 20x lens magnification carried out the microbiomorph investigation. Microbiomorphs were counted up to 300 specimens from one sample. The main categories of counted microbiomorphs are phytoliths, diatoms, sponge spicules, various plant spores, pollen, mycelium and fungal spores, zoogenic remains and foraminifera shells.

The following literature sources were used to determine the microbiomorph: 1) Pollen analysis; 2) Demske D. Atlas of pollen, spores and further non-pollen palynomorphs recorded in the glacial-interglacial late quaternary sediments of lake suigetsu, central japan; 3) Lyudmila Shumilovskikh, Guidelines for working with non-pollen palynomorphs; 4) Proshkina-Lavrenko A.I., Sheshukova V.S. Diatom collection and other. Phytoliths were determined based on illustrative material on the territory of Northern Altai (Solomonova et al., 2019).

\section{Results and Discussion}

Phytoliths (Figures 1, 2D and 2G) (about 90\%) silicon structures, which are formed in plant cells, are the basis of biogenic particles in the upper part of the microbiomorphic profile to the depth of $55 \mathrm{~cm}$. This is typical for soils under phytocenoses with grasses dominance (Solomonova et al., 2019). The phytoliths of grasses in the lake sapropel are half as much. Apparently, they belong to species, which grow along the banks of previously existing reservoir. Phytolith analysis revealed the dominance of reed phytoliths during the existence of the lake (Paradossky, 2019).

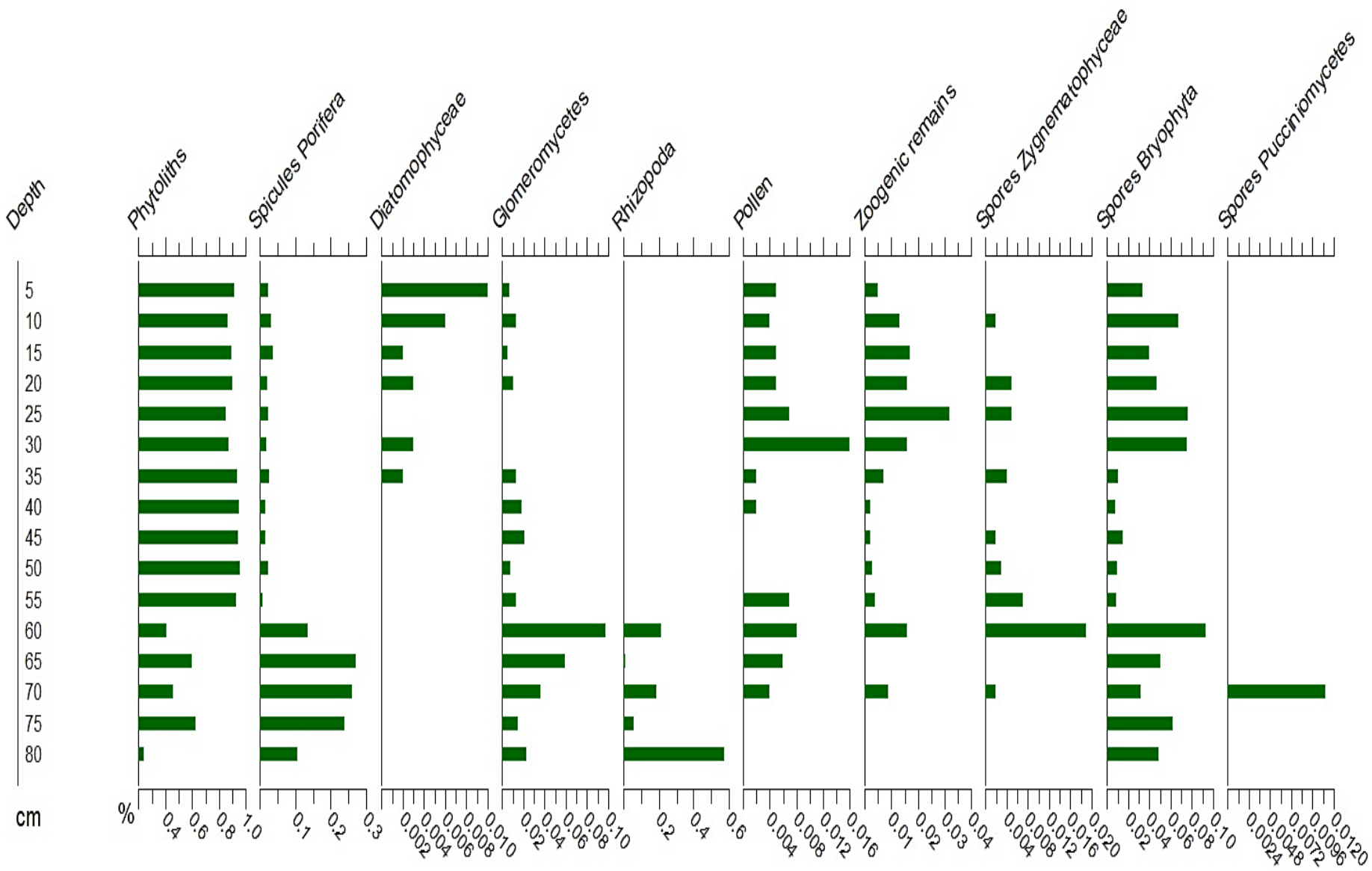

Figure 1. Microbiomorphic profile of a swampy meadow.

The shells of diatoms algae (Figures 2I-2M) are indicated among other silicon forms in the upper layers of the profile. These are the largest group of unicellular eukaryotic microalgae that are present in almost any aquatic environment (Gordov et al., 2013). Their presence corresponds to the presence of the present swampy phytocenosis.

Silica is also formed in freshwater and marine sponges (Figures $2 \mathrm{~N}$ and 20) (Gordova et al., 2013). Most types of the ordinary sponges class (Demospongiae), most representatives of Homoscleromorpha class, and all representatives of the glass sponges class (Hexactinellida) have the silicon skeleton (Drozdov, Karpenko, 2013). Sponge spicules are found over the entire depth in the investigated profile. Their largest number (from 10 to 25\%), as expected, is concentrated in the lake sapropel. The Demospongia class in the continental reservoirs of Western Siberia predominantly represents sponges; freshwater bodyagy and several other species are ordinary for modern ecosystems, (Sharapova et al. 2014). Remains of the sponges skeleton are often found during paleobotanical investigations the archaeological sites of Western Siberia located in floodplains of rivers and lakes (Sharapova et al. 2014).

Rhizopoda shells (Figures $2 \mathrm{H}$ and $2 \mathrm{P}$ ) are noted among the zoogenic residues in the profile. The amoeba shells are found in the wide variety of natural conditions: in moist mosses, soils, including fresh water (Imankulova et al., 2013; Imankulova, Lukyantseva, 2014; Zaidov, 1991). 

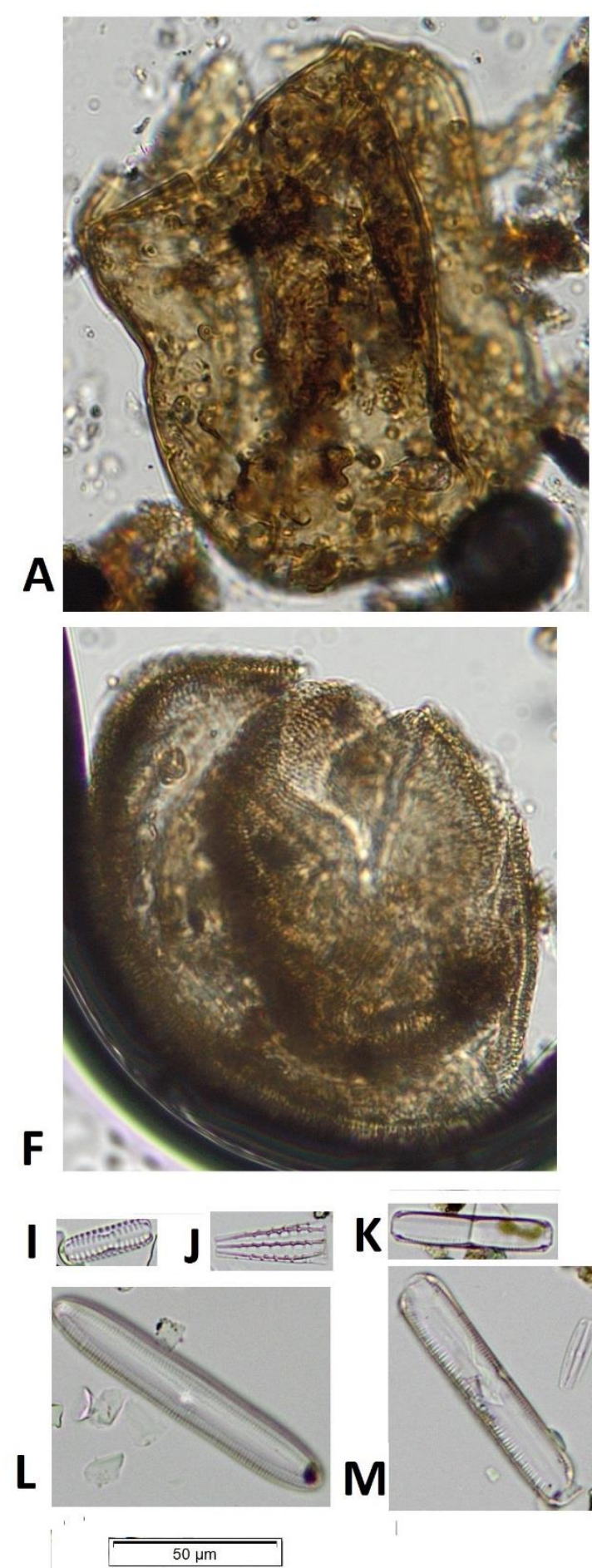
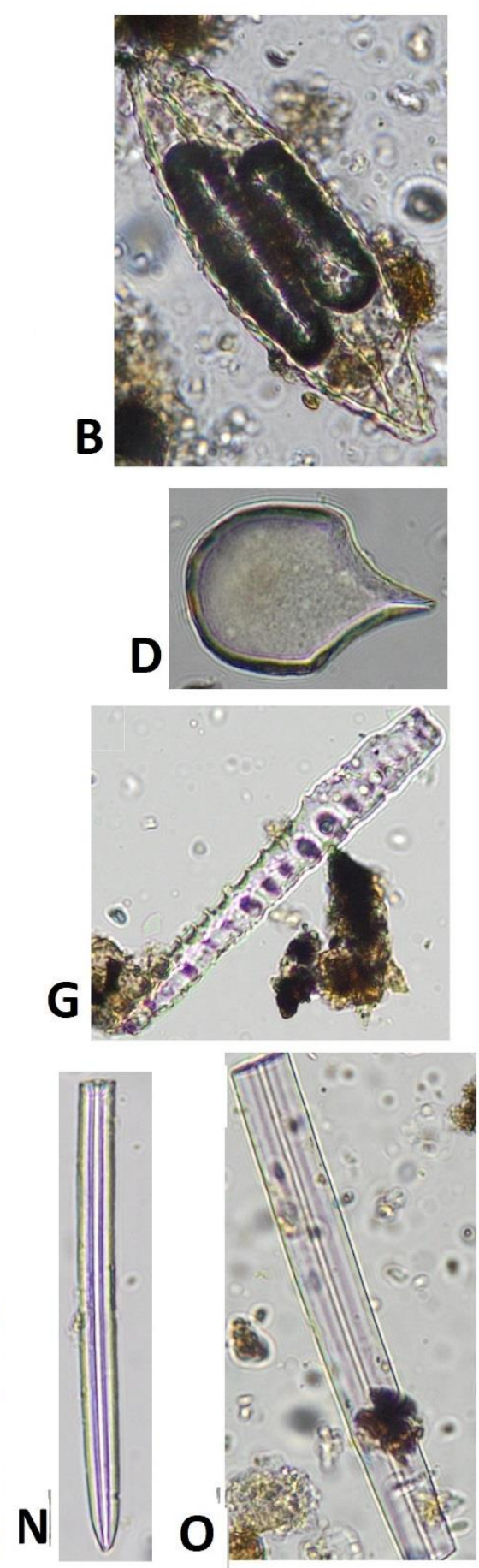
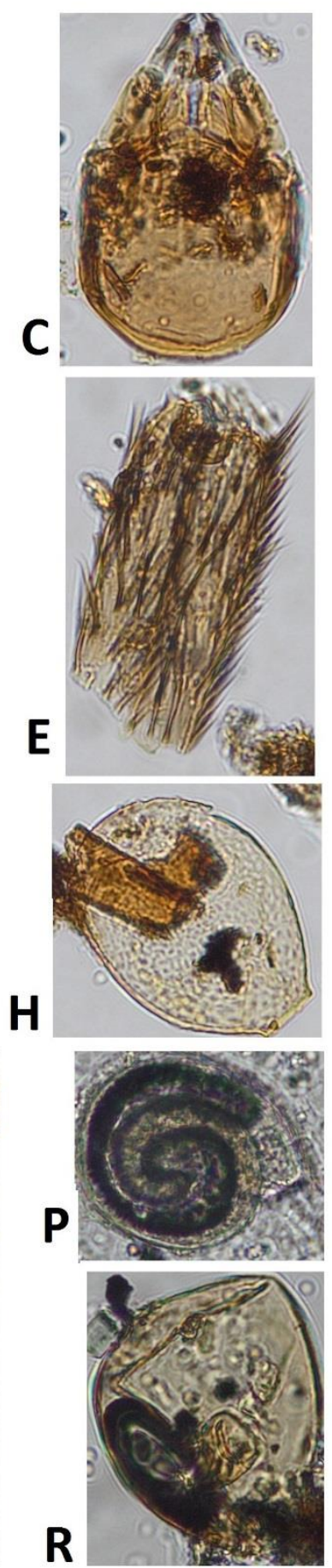

Figure 2. A - Rotifera oocyte; B - Zygnematophyceae spores; C, E - Insecta parts; D - Phragmites phytolith, F - Cladocera part; G - grass phytolith; H, P - Rhizopoda shells; I-M - Diatomophyceae; N, O - Sponge spicules; R - Dinoflagellata cyst.

The shells of these protozoa, although they have different degrees of preservation, can persist for long periods in peat deposits and be used for the indication of climatic conditions in paleoecological investigations as well as for reconstruction of the swamps water regime (Booth, 2001; Kuryina, 2011, 2015; Kuryina et al., 2010; Warner, Charman, 1994). The hydrological conditions of the investigated reservoir promoted the conservation of Rhizopoda shells only in the lake sapropel. Their large number in three layers of the profile: $55-60 \mathrm{~cm}, 65-70 \mathrm{~cm}$ and $75-80 \mathrm{~cm}$ is noticed. The decrease of shell amoebas in the profile correlates with increase the number of phytoliths. Thus, it should be assumed that the pulsation of the lake occurred in the holocene. In some years, the lake's mirror increased, in others it decreased and partially overgrown.

Other zoological residues (Figures 2A, 2C, 2E, 2F, 2R), besides the sponges spicules and amoeba shells, are found in the profile: insect fragments, parts of chitinous cover of rotifers and their oocytes, fragments of cladocera crustaceans, tardigrade eggs, which are evenly distributed throughout the profile in small quantities.

Spores of fungus, algae and mosses, as well as pollen represent the botanical material of the soil profile from coniferous and flowering plants. The spores of Glomeromycota (Figure 3A), endomycorrhizal fungus, which form arbuscular mycorrhiza and improve the mineral nutrition of plants, are mainly found in the lower layers of the profile. Their formation preceded the overgrowth of the reservoir (Belimov et al., 2012; Tchaikovskaya 2015). The reservoir was polluting at the time of the settlement's existence. The number of phosphates, which were more accessible to plants growing along its banks, increased (Goleva, Kiryushin, 2015), so, the mycorrhiza formation became less. 

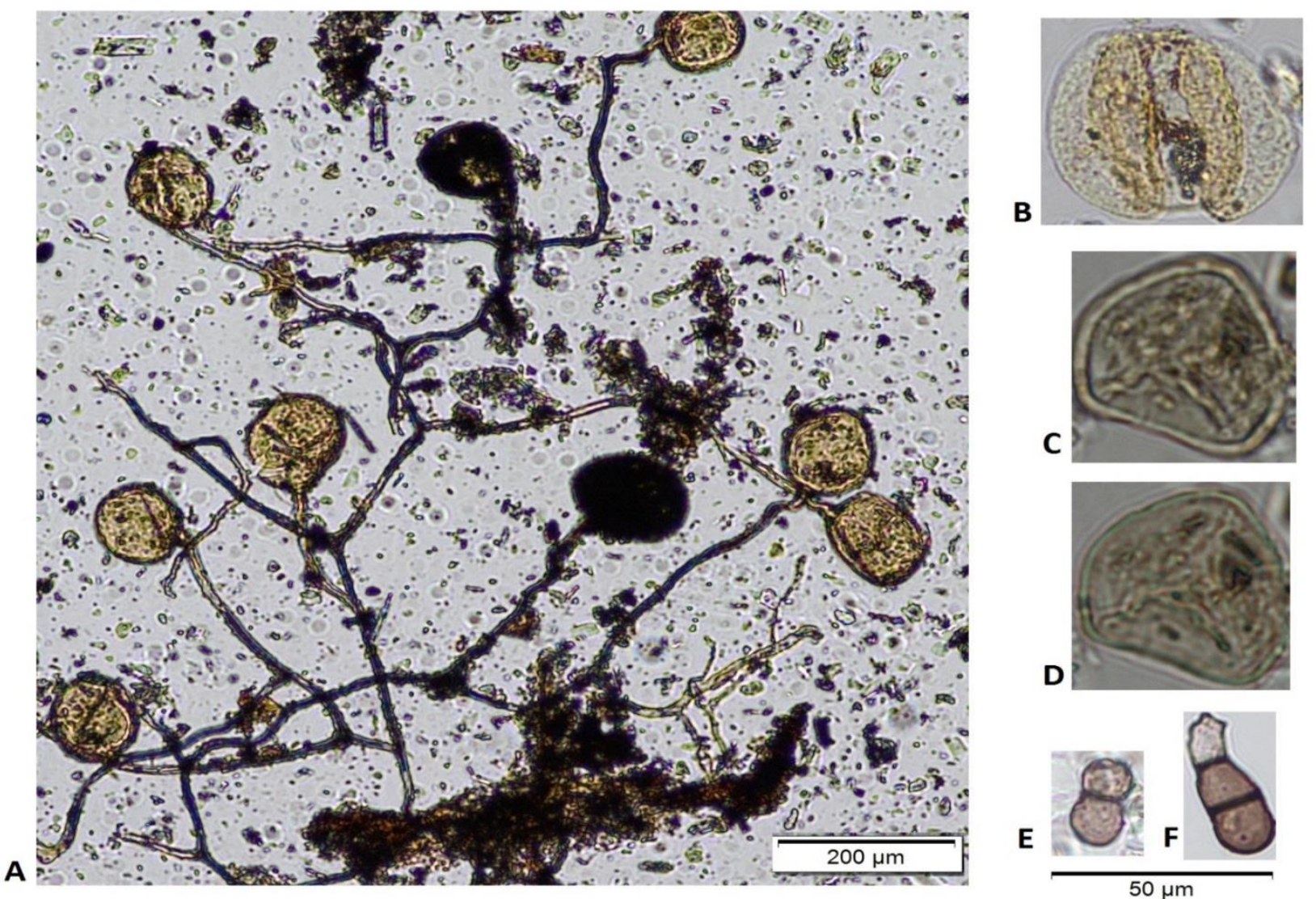

Figure 3. A - Glomus spores and gifs; B - Pinaceae pollen; C, D - Bryophyta spores; E, F- Pucciniomycetes spores.

Among fungus, Pucciniomycetes spores (Figures 3E and 3F) are also noted in small number in one layer. These are parasitic basidial fungus, which development occurs with the change of owners and several variants of sporulation (Rayimova et al., 2015).

Moss spores (Figures 3C and 3D) and pollen (Figure 3B) are found in small numbers throughout the whole profile. Palynological material usually has the high preservation of peat deposits of Siberia. Poverty of the samples by the pollen and spores is probably associated with the high rate of peat accumulation. The conjygat zygospores (Zygnematophyceae) (Figure 2B) with elongated form, which correspond to spores of zignem algae, are found in some layers of the profile. Ornamentation of spores is similar to the structure of Spirogyra, the freshwater alga, which is abundant in standing water (Janse, Vuuren, 2006). The significant number of these microbiomorphs was found in the layer of $55-60 \mathrm{~cm}$, which corresponds to the boundary of lake sapropel and peat. Thus, it was the freshwater standing water.

\section{Conclusion}

The microbiomorphic profile correlates with the morphology of the section. Initially, there was the fresh lake on the site, which was confirmed by the set of microbiomorphs. The water level in this pond was not constant and overgrowing was observed in some periods. The eneolithic settlement of people appeared on the shore of the lake approximately 4,200 yeas ago A.A. Goleva and K.Yu. Kiryushin found that people polluted the lake with household waste that led to its overgrowing (Goleva, Kiryushin, 2015). Despite the fact that people left this settlement subsequently, the hydrological regime of the reservoir did not recover. The reasons are the dry climate at the turn of the atlantic and subboreal period and the general tendency of intensification the waterlogging and peat accumulation processes in the subboreal period (Baulin et al., 1989; Rudaya et al., 2012; Zhilich et al., 2016). Waterlogging in the forest-steppe, besides the climatic factors, was caused by the presence of low-drained spaces with various negative landforms (Evseev, Zhilina, 2010).

\section{References}

Baulin, V.V., Vasil'chuk, V.K., Trofimov, V.T., Chekhovskij, A.L. (1989). Istoriko-geologicheskie zakonomernosti formirovaniya geokriologicheskih uslovij. Geokriologiya SSSR. Zapadnaya Sibir'. Moscow: Nedra, 20-38.

Belimov, A.A., Demchinskaya, S.V., Safronova, V.I. (2012). Reaction of pea plants on inoculation by rhizosphere 1aminocyclopropane-1-carboxylate (ACC) utilizing bacteria in the presence of endomycorrhizal fungus Glomus intraradices. Sel'skohozyajstvennaya biologiya, 3, 90-97. doi: 10.15389/agrobiology.2012.3.90eng. (in Russian).

Blinokhvatova, Yu.V., Embulaeva, E.A., Mazei, Yu.A. (2011). Soil-inhabited testate amoebae community structure in pine forests at different spatial scales. Izvestiya Penzenskogo gosudarstvennogo universiteta imeni V.G. Belinskogo, 25, 312-316. (in Russian).

Blyakharchuk, T.A. (2009). Western Siberia, a review of Holocene climatic changes. Journal of Siberian Federal University. Biology. $1(2), 4-12$.

Booth, R.K. (2001). Ecology of testate amoebae (Protozoa) in two Lake Superior coastal wetlands: implications for paleoecology and environmental monitoring. Wetlands, 21(4), 564-576.

Bulatova, U.A. (2010). Fauna and ecology of Testacea from pine forests of Tomsk and Kemerovo regions. Vestnik Tomskogo gosudarstvennogo universiteta. Biologiya, 2(10), 58-69. 
Bunting, M.J. (2008) Pollen in wetlands: using simulations of pollen dispersal and deposition to better interpret the pollen signal. Biodiversity and Conservation, 17, 2079-2096. doi: 10.1007/s10531-007-9219-x.

Cha, J.N., Shimizu, K., Zhou, Y. et al. (1999). Silicatein filaments and subunits from a marine sponge direct the polymerization of silica and silicones in vitro. Proceedings of the National Academy of Sciences, 96, 361-365. doi: 10.1073/pnas.96.2.361.

Cugny, C., Mazier, F., Galop, D. (2010). Modern and fossil non-pollen palynomorphs from the Basque mountains (western Pyrenees, France): the use of coprophilous fungi to reconstruct pastoral activity. Vegetation History and Archaeobotany, Springer Verlag, 391408. doi:10.1007/s00334-010-0242-6.

Demske, D., Tarasov, P.E., Nakagawa, T. (2013). Atlas of pollen, spores and further non-pollen palynomorphs recorded in the glacial-interglacial late quaternary sediments of lake suigetsu, central japan. Quaternary International, 290-291, 164-238. doi: 10.1016/j.quaint.2012.02.002.

Drozdov, F.L., Karpenko, A.A. (2013). Spicules of hexactinellid sponges (Hexactinellida: Porifera) as natural composite materials. Biologiya morya, 39(4), 237-245. doi: 10.1134/S1063074013040044. (in Russian).

Eckert, C., Schroeder, H.C., Brandt, D., Perovic-Ottstadt, S. et al. (2006). Histochemical and Electron Microscopic Analysis of Spiculogenesis in the Demosponge Suberites domuncula. Journal of Histochemistry and Cytochemistry, 54(9), 1031-1040. doi: 10.1369/jhc.5A6903.2006.

Evseeva, N.S., Zhilina, T.N. (2010). Paleogeografiya konca pozdnego plejstocena i golocena (korrelyaciya sobytij): uchebnoe posobie. Tomsk: Izdatel'stvo nauchno-tekhnicheskoj literatury.

Fedoruk, A.S., Papin, D.V., Rednikov, A.A., Frolov, Ya.V. (2017). Issledovaniya v Altajskom Priob'e i Kulunde. Arheologicheskie otkrytiya, 2015, 445-447.

Fedoruk, A.S. , Papin, D.V. , Fedoruk, O.A. (2018). Burla-3: Novye dannye o Burlinskom tipe pamyatnikov. Problemy arheologii, etnografii, antropologii Sibiri i sopredel'nyh territorij, 24, 315-318.

Goleva, A.A. (2001). Phytoliths and their information role in natural and archaeological objects. Moscow-Syktyvkar: Elista. doi: 10.14258/turczaninowia.21.4.11. (in Russian).

Goleva, A.A., Kiryushin, K.Yu. (2015). Harakteristika landshaftov perioda funkcionirovaniya poseleniya Novoil'inka-VI po dannym estestvennyh nauk. Arheologiya Zapadnoj Sibiri i Altaya: opyt mezhdisciplinarnyh issledovanij: sbornik statej, posvyashchennyj 70letiyu professora YU. F. Kiryushina. In Tishkin, A.A. (Ed). Barnaul: Izdatel'stvo AltGU, 110-115. (in Russian).

Gordova, V.S., Sapozhnikov, S.P., Sergeeva, V.E., Karyshev, P.B. (2013). The basics of biosilicification. Vestnik Chuvashskogo universiteta, 3, 401-409. (in Russian).

Hotinskij, N.A., Volkova, V.S., Levina, T.P., Liss, O.A. (1979). Hronologiya, periodizaciya i paleogeografiya golocena Zapadnoj Sibiri. Osobennosti geograficheskoj sredy $i$ istoricheskie processy v Zapadnoj Sibiri, 10-12.

Imankulova, E.A., Lukyantseva, L.V. (2014). Freshwater benthic testate amoebae in the conditions of anthropogenous influence. Estestvennye i matematicheskie nauki v sovremennom mire, 16, 159-163. (in Russian).

Imankulova, E.A., Pedunenko, E.N., Lukyantseva, L.V. (2013). Freshwater benthic testate amoebae from the Boyarskoe lake. Estestvennye i matematicheskie nauki v sovremennom mire, 13, 150-155. (in Russian).

Janse van Vuuren, S., Taylor, J., Gerber, A., van Ginkel, C. (2006). Easy identification of the most common freshwater algae. A guide for the identification of microscopic algae in South African freshwaters.

Khokhlova, O., Morgunova, N., Khokhlov, A., Golyeva, A. (2019). Dynamics of paleoenvironments in the Cis-Ural steppes during the mid- to late holocene. Quaternary Research, 91(1), 96-110. doi: 10.1017/qua.2018.23.

Kiryushin, K.Yu. (2017). Kompleks neolita - rannego eneolita poseleniya Novoil'inka-III (Severnaya Kulunda). Sohranenie i izuchenie kul'turnogo naslediya Altajskogo kraya, 23, 104-109.

Kiryushin, K.Yu. (2019). Eneolit Kulundinskoj stepi. In Tishkin A.A. (Ed.). V knige: Istoriya Altaya Gorbunov V.V., Grushin S.P., Dashkovskij P.K., Kiryushin K.YU., Kiryushin YU.F., Kungurov A.L., Matrenin S.S., Papin D.V., Seregin N.N., Stepanova N.F., Tishkin A.A., Fedoruk A.S., Fedoruk O.A., Frolov YA.V., SHamshin A.B., SHun'kov M.V. V 3-h tomah. Barnaul, 107-113.

Kurina, I.V. (2011). Ecology of testate amoebae as hydrological regime indicators in oligotrophic peatlands in the southern taiga of Western Siberia. Izvestiya Penzenskogo gosudarstvennogo universiteta imeni V.G. Belinskogo V.G. Belinskogo, 25, 368-375. (in Russian).

Kurina, I.V. (2015). Preservation of testate amoebae species in soils of oligotrophic peatlands. Otrazhenie bio-, geo-, antroposfernyh vzaimodejstvij v pochvah i pochvennom pokrove: sbornik materialov V Mezhdunarodnoj nauchnoj konferencii, posvyashchennoj 85letiyu kafedry pochvovedeniya i ekologii pochv TGU. Tomsk: Izdatel'stvo Tomskogo gosudarstvennogo universiteta, 329-331. (in Russian).

Kurina, I.V., Preisa, Yu. I., Bobrov, A. A. (2010). Testate Amoebae Inhabiting Middle Taiga Bogs in Western Siberia. Izvestiya RAN. Seriya biologicheskaya, 4, 423-429. (in Russian).

Lada, N.Yu., Gavrilov, D.A. (2016). Analysis of phytolith composition of the main plant steppe ecosystems of Western Siberia. Vestnik Tomskogo gosudarstvennogo universiteta. Biologiya, 2(34). 53-68. doi: 10.17223/19988591/34/4. (in Russian).

McCarthy, F.M.G., Riddick, N.L., Volik, O., Danesh, D.C., Krueger, A.M. (2018). Algal palynomorphs as proxies of human impact on freshwater resources in the Great Lakes region. Anthropocene, 21, 16-31. doi: 10.1016/j.ancene.2017.11.004.

Misumi, Sh.Y., Barros, M.A., Vilela, C.G., Barth, O.M. (2018). Non-Pollen Palynomorphs from Bottom Surface Sediments of "Lagoa Comprida" Lake, "Restinga de Jurubatiba" National Park, RJ, Brazil. Anuárdo Instituto de Geociências, 41, 344-350. doi: 10.11137/2018_2_344_350.

Orlova, L.A. (1990) Golocen Baraby. Stratigrafiya i radiouglerodnaya hronologiya. Novosibirsk: Nauka.

Paradossky, V. L. (2019). Phytoliths distribution by swampy meadow soil profile (North Kulunda). Problemy botaniki Yuzhnoj Sibiri $i$ Mongolii, 1(18), 350-353. doi:10.14258/pbssm.2019070

Paradossky, V.L., Solomonova, M.Yu. (2018). Microbiomorphic complex swampy meadows of Northern Kulunda. In: Belanova A.P. (Ed). V sbornike: Perspektivy razvitiya i problemy sovremennoj botaniki Materialy IV (VI) Vserossijskoj molodezhnoj konferencii s uchastiem inostrannyh uchenyh, 168-170.

Poulsen, N., Sumper, M., Kröger, N. (2003). Biosilica formation in diatoms: Characterization of native silaffin-2 and its role in silica morphogenesis. PNA, 100(21), 12075-12080. doi: 10.1073/pnas.2035131100.

Proshkina-Lavrenko, A.I., Sheshukova, V.S. (1953). Diatomovyj sbornik. Leningrad: Izdate/'stvo leningradskogo gosudarstvennogo universiteta. (in Russian).

Pyl'cevoj analiz (1950). In: Pokrovskaya, I.M. (Ed.). Moskow: Gosgeolitizdat. (in Russian).

Rakhimova, Y. V.,Nam, G. A., Yermekova, B. D., Abiyev, S. A., Jetigenova, U. K., Yessengulova, B. Zh. (2015). Key to the rust fungi of the Kazakhstan. Turczaninowia, 18(3), 5-65. DOI: 10.14258/turczaninowia.18.3.1 
Rudaya, N., Nazarova, L., Nourgaliev, D., Palagushkina, O., Papin, D. Frolova, L. (2012). Mid-late Holocene environmental history of Kulunda, southern West Siberia: vegetation, climate and humans. Quaternary Science Reviews, 48, 32-42. doi: 10.1016/j.quascirev.2012.06.002.

Rudaya, N.A. (2018). Vegetation Changes in Kulunda During the Late Pleistocene and Holocene: First Results of the Pollen Study of Lake Kuchuk Bottom Sediments. Problemy arheologii, etnografii, antropologii Sibiri i sopredel'nyh territorij, 24, 146-149. doi: 10.17746/2658-6193.2018.24.146-149.

Rudaya, N.A., Zhilich, S.V., Bayarkhuu, B., Cao, X., Darin, A.V., Frolova, L.A., Kalugin, I.A., Krivonogov, S.K., Nazarova, L.B., Otgonbayar, D., Palagushkina, O.V., Slusarenko, I.Y., Syrykh, L. (2018). Environments of Southwestern Siberia and Northwestern Mongolia in the late holocene (based on the lake sediments study). Paleolimnology of Northern Eurasia: experience, methodology, current status and young scientists school in microscopy skills in paleolimnology Proceedings of the 3rd International Conference, 94-96.

Rusakov, A., Sorokin, P., Golyeva, A., Savelieva, L., Rusakova, E., Safronov, S. (2018). Soils of a medieval burial mound as a paleoenvironmental archive (Leningrad region, Northwest Russia). Bulletin of the Geological Society of Finland, 90(2), 315-325. doi: $10.17741 /$ bgsf/90.2.013

Sharapova, T.A., Trylis, V.V., Ivanov, S.N., Ilyushina, V.V. (2014). The composition and distribucion of sponges (Porifera) in continental waters of Western Siberia. Sibirskij ekologicheskij zhurnal, 5, 719-727. doi: 10.1134/S1995425514050138. (in Russian).

Shumilovskih, L.S. (2016). Rukovodstvo po rabote s nepyl'cevymi palinomorfami. Biogennye arhivy landshaftnyh izmenenij proshlogo. Materialy vserossijskoj shkoly-konferencii molodyh uchenyh $s$ mezhdunarodnym uchastiem. Tomsk: Izdatel'stvo Tomskogo universiteta. (in Russian).

Silant'eva, M.M. (2008). Flora Altajskogo kraya: analiz i istoriya formirovaniya. Diss... dok. biol. nauk: 03.02.01. Barnaul.

Sitnikov, S.M. (2014). K arheologicheskoj karte Habarskogo rajona. Sohranenie i izuchenie kul'turnogo naslediya Altajskogo kraya, 20, 177-184.

Solomonova, M. Y., Speranskaya, N. Y., Blinnikov, M. S., Kharitonova, E. Y., Pechatnova, Y. V., Silantieva, M. M. (2018). Cyperaceae Juss. and Juncaceae A. Rich ex Kunt. phytoliths of Western Siberia. Ukrainian Journal of Ecology, 8(4), $332-334$.

Solomonova, M.Y., Blinnikov, M.S., Silantieva, M.M., Speranskaya, N.Y. (2019). Influence of Moisture and Temperature Regimes on the Phytolith Assemblage Composition of Mountain Ecosystems of the Mid Latitudes: A Case Study From the Altay Mountains. Frontiers in Ecology and Evolution. doi: 10.3389/fevo.2019.00002.

Solomonova, M.Yu., Kiryushin, K.Yu., Silant'eva, M.M., Speranskaya, N.Yu. (2016). Paleopochvennye issledovaniya arheologicheskih ob"ektov eneolita Severnoj Kulundy. V knige: Mezhdisciplinarnoe izuchenie arheologii Zapadnoj Sibiri i Altaya tezisy dokladov otchetnoj sessii, 70-71.

Solomonova, M.Yu., Kiryushin, K.Yu., Sitnikov, S.M. (2017). Phytoliths research of the Novoilinka and Novoilinka-1 bronze age archaeological sites (North Kulunda). Izvestiva Altajskogo gosudarstvennogo universiteta, 5(97), 218-222. doi: 10.14258/izvasu(2017)5-39.

Solomonova, M.Yu., Speranskaya, N.Yu., Silantieva, M.M., Mitus, A.A. (2015). Incidence of phytoliths at form of trapezium-shape short particles of grasses of different ecological groups in the south of Western Siberia. Problemy botaniki Yuzhnoj Sibiri i Mongolii, 14, 295-300. doi: 10.14258/turczaninowia.21.4.11. (in Russian).

Speranskaya, N.Yu., Solomonova, M.Yu., Geynrich, Yu.V. (2016). The soil phytoliths analysis of meadow and steppe phytocenoses in Altai region. Dinamika okruzhayushchej sredy i global'nye izmeneniya klimata, 7, (1)(13), 148-154. doi: 10.17816/edgcc71148154. (in Russian).

Tchaikovskaya, L.A. (2015). The development of Glomus fasciculatum in roots of Sorghum Sudanense. Estestvennye $i$ matematicheskie nauki v sovremennom mire, 26, 133-138. (in Russian).

Thamatrakoln, K., Hildebrand, M. (2008). Silicon Uptake in Diatoms Revisited: A Model for Saturable and Nonsaturable Uptake Kinetics and the Role of Silicon Transporters. Plant Physiology, 146, 1397-1407. doi: 10.1104/pp.107.107094.

Tsuchikane, Y., Tsuchiya, M., Hinda'k, F., Nozaki, H., Sekimoto, H. (2012). Zygospore formation between homothallic and heterothallic strains of Closterium. Sex Plant Reprod, 25, 1-9. doi: 10.1007/s00497-011-0174-z.

Warner, B.G., Charman, D.J. (1994). Holocene changes on a peatland in northwestern Ontario interpreted from testate amoebae (Protozoa) analysis. Boreas, 23, 271-279.

Zaidov, T.F. (1997). Pochvennye rakovinnye ameby Zakatal'skogo rajona Azerbajdzhana. Zoologicheskij zhurnal, 79(4), 132-134. (in Russian).

Zhilich, S., Rudaya, N., Pozdnyakov, D., Krivonogov, S., Nazarova, L. (2017). Environmental dynamics of the Baraba forest-steppe (Siberia) over the last 8000 years and their impact on the types of economic life of the population. Quaternary Science Reviews,163, 152-161. doi: 10.1016/j.quascirev.2017.03.022.

Zhilich, S.V., Rudaya, N.A., Krivonogov, S.K. (2016). Late holocene climate and vegetation changes. Dinamika okruzhayushchej sredy i global'nye izmeneniya klimata, 7(1)(13), 68-75. doi: 10.17816/edgcc7168-75.

Zurzolo, C., Bowler, C. (2001). Exploring Bioinorganic Pattern Formation in Diatoms. A Story of Polarized Trafficking. Plant Physiology, 127, 1339-1345. doi: 10.1104/pp.010709.

Zykin, V.S., Zykina, V.S., Orlova, L.A., Savel'eva, P.Yu., Sizikova, A.O., Smolyaninova, L.G. (2011). Upper cenozoic of the south of Western Siberia: Current status of stratigraphy and paleogeography. Novosti paleontologii i stratigrafii, 16-17, 137-152.

\section{Citation:}

Paradossky, V.L., Pechatnova, Yu.V., Solomonova, M. Yu. (2019). The natural transformations of the Northern Kulunda in the second half of the Holocene based on studying the microbiomorphic profile of swampy phytocenosis. Ukrainian Journal of Ecology, 9(3), 406-411.

\begin{tabular}{|l|l}
$(\mathrm{cc}) \mathrm{EY}$ \\
$\mathrm{Er}$
\end{tabular} 